\section{SURGICAL MANAGEMENT OF NEONATAL COARCTATION}

Between 1983 and 1994, 307 consecutive neonates underwent coarctation repair by a single surgical technique: extended end-to-end anastomosis. Mean age at operation was $13 \pm 8$ days. Isolated coarctation was present in 95 patients (group 1), 102 patients had associated ventricular septal defect (group 2), and 110 patients had associated complex intracardiac lesions (group 3). Aortic arch hypoplasia was present in $81 \%$ of the patients (62\% in group 1 versus $85 \%$ in group 2 and 93\% in group $3: p<0.001$ ). In 271 patients, the aortic arch reconstruction was performed via a left thoracotomy with normothermia (100\% of group 1, $95 \%$ of group 2, and $72 \%$ of group 3 ); in the other 36 patients, undergoing one-stage repair or palliation of the associated lesion, it was performed via a midline sternotomy during a short period of deep hypothermia and circulatory arrest (5\% of group 2 and $28 \%$ of group 3). Pulmonary artery banding was performed in 94 patients. Spontaneous ventricular septal defect closure was observed in 39\% of the patients of group 2 operated on via thoracotomy. Early mortality rates in groups $1(2 \%)$ and $2(2 \%)$ were significantly lower than in group $3(17 \%)(p<0.001)$. There were 29 late deaths, all related to associated cardiac lesions or their subsequent repair. The overall total mortality was $16.9 \%$. In group 3 this rate was significantly higher in patients undergoing two-stage procedures $(47 \%)$ than in those undergoing one-stage repair $(23 \%)(p<\mathbf{0 . 0 5})$. All but 14 survivors were followed up for a mean of $61 \pm 36$ months. Actuarial survivals at 10 years were $98 \%$ in group 1, 94\% in group 2 , and $60 \%$ in group 3 . The recoarctation rate was $9.8 \%$, leading to 21 reoperations and three angioplasties without mortality. Patients with a more extended or severe form of aortic arch hypoplasia had a significantly higher risk of recoarctation $(p<0.001)$. Actuarial freedom from reoperation for recoarctation at 10 years was $93 \%$. The findings of this study suggest that extended end-to-end anastomosis provides an adequate and safe repair of neonatal coarctation. Low recoarctation rate, owing to effective relief of the obstruction created by aortic arch hypoplasia and to complete resection of ductal tissue, freedom from major morbidity, and feasibility via both lateral and anterior approaches are the main advantages of the extended end-to-end anastomosis. Mortality is mainly dependent on the complexity of the cardiac associations. Successful management of the majority of the neonates with coarctation and associated ventricular septal defect is possible with repair of coarctation alone. One-stage repair of neonatal coarctation and associated complex heart defects (with indication for two-ventricle repair) by means of an anterior approach provides a better outcome than a two-stage repair. (J THORAC CARDiovasc Surg 1995;109:663-75)

S. Conte, MD (by invitation), F. Lacour-Gayet, MD (by invitation), A. Serraf, MD (by invitation), M. Sousa-Uva, MD (by invitation), J. Bruniaux, MD (by invitation), A. Touchot, MD (by invitation), and C. Planché, MD (by invitation),

Le Plessis Robinson, France

Sponsored by Aldo Castaneda, MD, Boston, Mass.
From the Department of Pediatric Cardiac Surgery, MarieLannelongue Hospital, Paris Sud University, Le Plessis Robinson, France.

Read at the Seventy-third Annual Meeting of The American Association for Thoracic Surgery, Chicago, Ill., April 25-28, 1993, by F. Lacour-Gayet, MD.

Address for reprints: F. Lacour-Gayet, MD, Marie-Lannelongue Hospital, 133 Avenue de la Résistance, 92350 Le Plessis Robinson, France.

Copyright (C) 1995 by Mosby-Year Book, Inc.

$0022-5223 / 95 \$ 3.00+0 \quad \mathbf{1 2 / 6 / 6 2 0 4 0}$
The results of the surgical management of neonatal coarctation have constantly been improved since Mustard and associates ${ }^{1}$ performed the first successful repair in 1953. The introduction of the preoperative use of prostaglandin $\mathrm{E}_{1}^{2}$ and the development of a surgical technique providing an effective reconstruction of the entire aortic arch, ${ }^{3-6}$ often hypoplastic in symptomatic neonates with aortic coarctation, ${ }^{7-11}$ have been extremely important. Since 1983 we $^{12}$ have tried to correct neonatal 
coarctation by a single surgical procedure either via thoracotomy or via sternotomy (when repair of associated intracardiac lesions was attempted in the mean stage): resection and extended end-to-end anastomosis. The purpose of this paper is to review our 11 years of experience with aortic coarctation repair in 307 neonates treated by extended end-toend anastomosis.

\section{Patients and methods}

Definitions. The aortic arch was defined as lying between the brachiocephalic artery and the ductus arteriosus and as comprising three segments: the proximal transverse arch, between the brachiocephalic and left carotid arteries, the distal transverse arch, between the left carotid and left subclavian arteries, and the isthmus, between the left subclavian artery and the ductus arteriosus. Anatomic features of the aortic arch were carefully evaluated by both the cardiologist at the time of diagnosis and the surgeon at the time of operation. The criterion for defining aortic arch hypoplasia was a diameter of proximal transverse arch, distal transverse arch, and isthmus less than, respectively, $60 \%, 50 \%$, and $40 \%$ of that of the ascending aorta. ${ }^{13}$ Three types of aortic arch hypoplasia were defined according to the location: distal aortic arch hypoplasia (hypoplasia of distal transverse arch and isthmus), complete aortic arch hypoplasia (hypoplasia of the entire aortic arch), and complex aortic arch hypoplasia (very short proximal arch associated with a very long and hypoplastic distal transverse arch and isthmus).

With regard to the associated anomalies, any heart defect having a surgical indication was considered as a complex intracardiac lesion if other than a ventricular septal defect (VSD). Early mortality was calculated as the rate of deaths within the first 30 postoperative days or before hospital discharge. Any postoperative stenosis in the repair area giving a resting peak pressure gradient of greater than $20 \mathrm{~mm} \mathrm{Hg}$ at Doppler was considered as a recoarctation. ${ }^{10}$ More precisely, it was defined as residual coarctation when the gradient was detected during the postoperative hospital stay or as recurrent coarctation when the gradient was detected after discharge from the hospital. Any postoperative respiratory failure, left ventricular dysfunction, and blood hypertension necessitating, respectively, ventilatory support, inotropic support, and medical treatment for more than 15 days were defined as persistent.

Patient population. Between 1983 and 1994, 307 consecutive neonates ( $\leq 30$ days old) underwent surgical repair of aortic coarctation by extended end-to-end anastomosis at the Marie Lannelongue Hospital, Paris. Patients in whom coarctation of the aorta was part of a true hypoplastic left heart syndrome (class IV) ${ }^{10}$ were not included. There were 191 boys and 116 girls. Mean age, weight, and body surface area at operation were, respectively, $13 \pm 8$ days, $3.2 \pm 0.6 \mathrm{~kg}$, and $0.20 \pm 0.02 \mathrm{~m}^{2}$. The indication for operation in all cases was congestive heart failure. Ductal patency was maintained preoperatively with prostaglandin $\mathrm{E}_{1}$ infusion in 221 patients (72\%), 168 of them in the last 5 years. The prevalence of prostag- landin $\mathrm{E}_{1}$ therapy has increased from $40 \%$ in the period $1983-1989$ to $96 \%$ in the period 1990-1994 $(p<0.001)$. Preoperative ventilatory and inotropic supports were given in $150(49 \%)$ and $111(36 \%)$ patients, respectively. A correct fetal diagnosis was obtained in 28 patients $(9 \%)$. Cardiac catheterization was performed in 74 patients (24\%); in the remainder, the diagnosis was made clinically and confirmed with two-dimensional echocardiography $(p<0.001)$.

The patients were divided by their additional cardiovascular defects into groups 1 to 3 (Table I). Group $1(n=$ 95) included those with isolated coarctation, group $2(n=$ $102)$ those with associated VSD, and group $3(n=110)$ those with associated complex intracardiac lesions.

Aortic arch hypoplasia was present in 248 patients (81\%): 59 in group $1(62 \%), 87$ in group $2(85 \%)$, and 102 in group 3 (93\%) (group 1 versus groups 2 or 3: $p<$ 0.001 ). All three types of aortic arch hypoplasia were encountered: distal in 169 patients, complete in 59, and complex in 20. Complete and complex aortic arch hypoplasia were observed significantly more often in patients with associated major intracardiac lesions $(p<0.001)$ (Table II).

Operative technique. Since 1983 all the neonates referred for coarctation repair underwent aortic arch reconstruction by extended end-to-end anastomosis. Two surgical approaches were used: left posterolateral thoracotomy in the third intercostal space in 271 patients $(88 \%)$ and midline sternotomy in 36 patients $(12 \%)$.

Extended end-to-end anastomosis was performed via thoracotomy in all patients of the group 1 and in those in groups 2 or 3 considered for intracardiac repair in a second stage (see Table I). The technique was previously reported by our group. ${ }^{12}$ The arterial pressure was monitored by means of a catheter in the right radial artery. Care was taken to keep the patient normothermic during the procedure. The entire thoracic aorta including all its branches was widely dissected to allow an extensive mobilization all over, from the ascending aorta proximally to the level of the fourth set of intercostal arteries distally. The ductus arteriosus was primarily divided between two ligations to allow more easily free dissection of proximal transverse arch and ascending aorta. Intercostal arteries were rarely divided. Aggressive proximal and distal mobilization is mandatory part of this technique to avoid any tension at the anastomosis (Fig. 1).

A curved vascular clamp of appropriate size was used to crossclamp the proximal transverse arch as proximally as possible, including the left carotid artery, while checking unobstructed forward flow to the innominate artery by a radial arterial line. The left subclavian artery was clamped as well, except in seven patients with a complex aortic arch hypoplasia, in whom it was either ligated before part of the distal transverse arch was resected or used as a flap to augment the top of the distal arch. In all the patients $(n=$ 4) with anomalous origin of the right subclavian artery (from the upper descending aorta), this was ligated and resected. Another curved vascular clamp was used to crossclamp the descending aorta at the level of the first-second set of intercostal arteries. After placement of both proximal and distal clamps, the coarctation was 
Table I. Neonatal coarctation and associated cardiac anomalies: Type of surgical approach

\begin{tabular}{|c|c|c|c|c|}
\hline Anomaly & No. (rate) & \multicolumn{2}{|c|}{ Thoracotomy No. (rate) } & $\begin{array}{c}\text { Sternotomy } \\
\text { No. (rate) }\end{array}$ \\
\hline \multicolumn{5}{|l|}{ Group 1} \\
\hline Isolated coarctation & $95(31 \%)$ & & & 0 \\
\hline \multicolumn{5}{|l|}{ Group 2} \\
\hline Coarctation with VSD & $102(33 \%)$ & & (48 PAB) & $5(5 \%)$ \\
\hline Single VSD & 76 & 71 & $(22 \mathrm{PAB})$ & 5 \\
\hline Multiple VSD & 26 & 26 & $(26 \mathrm{PAB})$ & - \\
\hline \multicolumn{5}{|l|}{ Group 3} \\
\hline Coarctation with complex heart defect & $110(36 \%)$ & & $(46 \mathrm{PAB})$ & $31(28 \%)$ \\
\hline TGA or DORV + VSD & 59 & 35 & (32 PAB) & 24 \\
\hline TGA + IVS & 12 & 9 & & 3 \\
\hline UH & 10 & 7 & (7 PAB) & 3 \\
\hline HLV & 7 & 7 & & - \\
\hline Aortic valve stenosis & 6 & 6 & & - \\
\hline Aortic + mitral valve stenosis & 6 & 6 & & - \\
\hline CTGA + VSD & 4 & 4 & (4 PAB) & - \\
\hline CAVSD & 3 & 3 & (3 PAB) & - \\
\hline Mitral regurgitation & 2 & 2 & & - \\
\hline Aortopulmonary window & 1 & - & & 1 \\
\hline
\end{tabular}

$V S D$, Ventricular septal defect; TGA, transposition of the great arteries; $D O R V$, double-outlet right ventricle; $I V S$, intact ventricular septum; $U H$, univentricular heart; $H L V$, hypoplastic left ventricle; $C T G A$, corrected transposition of the great arteries; $C A V S D$, complete atrioventricular septal defect; $P A B$, pulmonary artery banding.

widely resected, with removal of any ductal tissue. A longitudinal incision was made in the undersurface of the arch and extended proximal to the origin of the left carotid artery. The extension of this incision was more limited when aortic arch hypoplasia was absent (19\%). An incision was then made in the posterolateral aspect of the descending aorta so that the diameter in the two aortic ends would be equal (Fig. 2).

The anastomosis was performed with continuous 6-0 polypropylene suture. It was begun proximally on the arch with all the loops of the posterior aspect inserted before the two clamps were approximated, the suture tightened, and the anterior aspect completed (Fig. 3). The mean crossclamp time was $22 \pm 10$ minutes (range 14 to 38 minutes) and the mean postoperative gradient was $5 \pm 6$ $\mathrm{mm} \mathrm{Hg}$ (range 0 to $24 \mathrm{~mm} \mathrm{Hg}$ ).

Pulmonary artery banding (PAB) was performed as an additional procedure in 94 of 176 patients of groups 2 and 3 undergoing extended end-to-end anastomosis via thoracotomy $(53 \%)$. In group 2, PAB was performed in all the patients with multiple VSDs and in just $31 \%$ of those with a single VSD. Spontaneous VSD closure was observed with time in $39 \%$ of the patients of group 2 operated on via thoracotomy (38/97).

Extended end-to-end anastomosis was performed through a sternotomy in five patients of group 2 and in 31 of group 3, undergoing one-stage repair or palliation of the associated lesion (see Table I). After the institution of cardiopulmonary bypass (CPB), the aortic arch was first reconstructed during a short period of deep hypothermia and total circulatory arrest according to the aforementioned principles. The mean circulatory arrest time was $31 \pm 11$ minutes (range 19 to 58 minutes) and the mean postoperative gradient was $6 \pm 7.5 \mathrm{~mm} \mathrm{Hg}$ (range 0 to 25 $\mathrm{mm} \mathrm{Hg}$ ). After completion of arch repair, the distal clamp
Table II. Distribution of the different types of aortic arch hypoplasia according to associated cardiac anomalies

\begin{tabular}{cccc}
\hline $\begin{array}{c}\text { Patient } \\
\text { groups }\end{array}$ & $\begin{array}{c}\text { Distal AAH } \\
(n=169)\end{array}$ & $\begin{array}{c}\text { Complete AAH } \\
(n=59)\end{array}$ & $\begin{array}{c}\text { Complex AAH } \\
(n=20)\end{array}$ \\
\hline Group 1 & 51 & $8(\alpha)$ & $0(\delta)$ \\
Group 2 & 56 & $23(\beta)$ & $8(\epsilon)$ \\
Group 3 & 62 & $28(\chi)$ & $12(\phi)$ \\
\hline
\end{tabular}

Group 1, Isolated coarctation; group 2, coarctation with VSD; group 3, coarctation with complex heart defect; $A A H$, aortic arch hypoplasia. $\alpha(=$ $14 \%)$ versus $\beta+\chi(=86 \%): p<0.001 ; \delta(=0)$ versus $\epsilon+\phi(=100 \%)$ : $p<0.001$.

and head vessel snares were removed and low-flow CPB was resumed. After deairing, flow was returned to normal and intracardiac repair followed.

In group 2, among the patients operated on via this approach, three had a very large VSD, two had a complex aortic arch hypoplasia, and one had both these anomalies.

In group 3, the anterior approach was used in 27 patients undergoing repair of transposition of the great arteries (with or without VSD) or double-outlet right ventricle (TGA-DORV) by arterial switch, in one patient undergoing aortopulmonary window repair, and in three patients undergoing palliation of univentricular heart with TGA and subaortic stenosis by arterial switch. Five of these patients had a complex aortic arch hypoplasia. Among the patients of group 3, the prevalence of onestage repair has increased from $8 \%(5 / 61)$ in the period 1983-1989 to 53\% (26/49) in the period 1990-1994 $(p<$ 0.001 ).

Follow-up. Two hundred seventy of 284 hospital survivors $(95 \%)$ were followed up for a mean of $61 \pm 36$ 


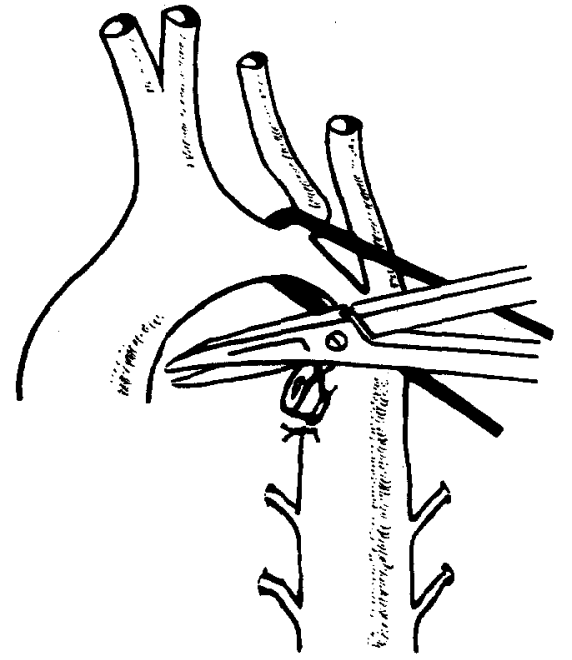

Fig. 1. Wide dissection and mobilization of the entire thoracic aorta after division of the ductus arteriosus.

months (range 3 months to 11 years). Follow-up data were obtained from the referring pediatric cardiologists. Routine echocardiographic studies, including two-dimensional echocardiography and Doppler assessment of pressure gradients, were carried out at varying intervals during follow-up. Patients with recoarctation underwent a complementary angiography.

Statistical analysis. Continuous data are presented as means \pm standard deviation. Proportions are accompanied by their $95 \%$ confidence limits (CL). Statistical comparisons were evaluated by the $\chi^{2}$ test and actuarial estimates were calculated with the Kaplan-Meier method.

\section{Results}

Mortality. The overall early mortality was $7.5 \%$ $(23 / 307 ; \mathrm{CL}=4.5 \%$ to $10.4 \%)$. Early mortality rates in groups $1(2 \%)$ or $2(2 \%)$ were significantly lower than in group $3(17 \%)(p<0.001)$. The overall late mortality was $10.7 \%(29 / 270 ; \mathrm{CL}=7 \%$ to $14.4 \%)$, and significant differences still persisted between groups 1 (no late deaths) or $2(4 \%)$ and group 3 $(28 \%)(p<0.001)$ (Table III).

In group 1 , both early deaths occurred at the beginning of our experience and were caused by ventricular fibrillation after an acute declamping syndrome.

In group 2, one early death was due to low cardiac output related to biventricular obstruction in a patient with residual coarctation and $\mathrm{PAB}$, and the other was due to congestive heart failure. In the same group all late deaths occurred at a secondstage VSD closure: one was related to an abnormal coronary artery injury, one was related to a "Swiss

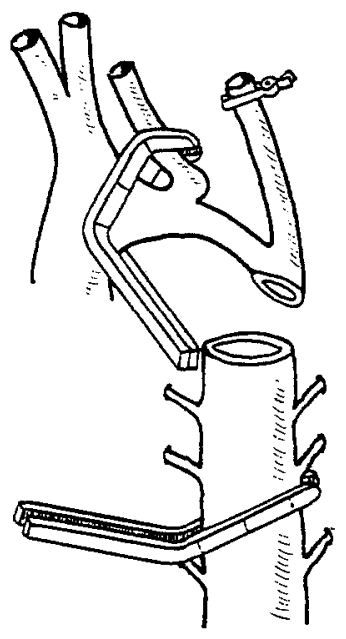

A

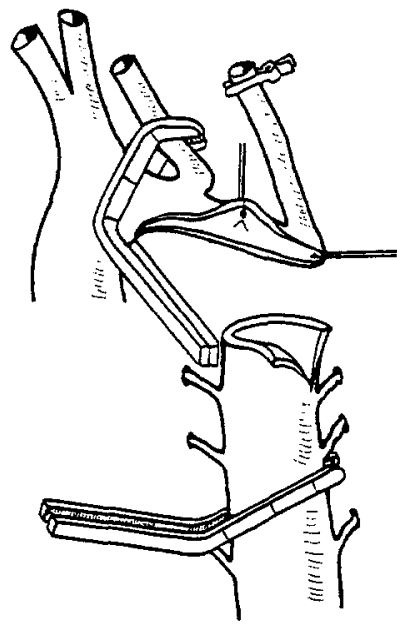

B
Fig. 2. Resection of coarctation including all ductal tissue (A) and extended incision in the arch concavity (B) after placement of the clamps.

cheese type" multiple VSD closure, and two were sudden deaths. No deaths occurred among patients operated on in a single stage via sternotomy.

In group 3, only two early deaths were in relation to a residual coarctation; the other early deaths and all late deaths were in relation to the associated lesions or their subsequent repair.

The overall total mortality was $16.9 \%$ (52/307; CL $12.7 \%$ to $21.1 \%$ ). In group 3 this rate significantly decreased from $49 \%$ in the period $1983-1989$ to $29 \%$ in the period 1990-1994 $(p<0.05)$. In the same group, a significant difference was present as well between total mortality rates among patients undergoing two-stage $(47 \%)$ and one-stage $(23 \%)$ repair or palliation of the intracardiac defect $(p<0.05)$. Because the majority $(87 \%)$ of the patients undergoing a one-stage procedure had a TGA-DORV repair, a comparison between one- and two-stage repairs in this last subgroup became mandatory: total mortality rate in patients undergoing two-stage repair $(45 \%)$ was significantly higher than in patients undergoing one-stage repair $(19 \%)(p<0.05)$ (see Table III).

Survival. The overall actuarial probability of survival at 10 years after operation, including operative mortality, was $83 \% \pm 4 \%$. According to associated anomalies, 10-year actuarial survival rates were $98 \% \pm 3 \%$ in group $1,94 \% \pm 5 \%$ in group 2 , and $60 \% \pm 9 \%$ in group 3 (Fig. 4). 


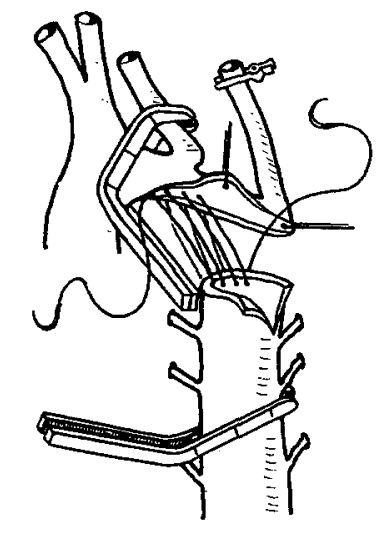

A

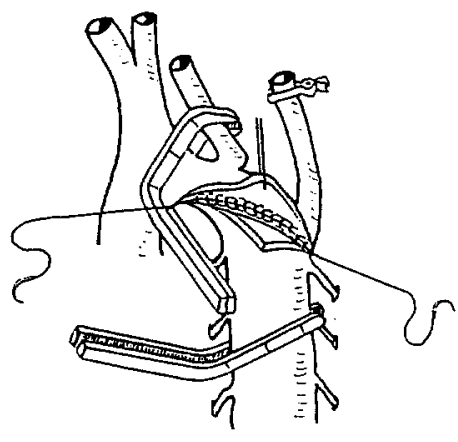

B

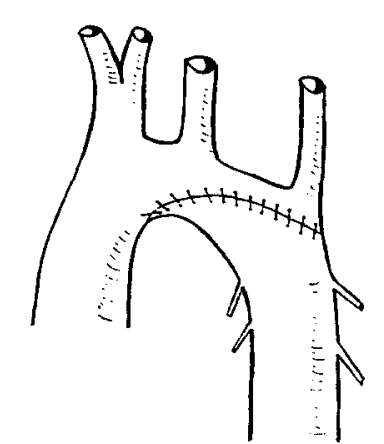

C

Fig. 3. The anastomosis is begun at the posterior aspect (A) and completed after the clamps had been approached and the suture tightened (B and $\mathbf{C})$.

Table III. Mortality according to associated cardiac anomalies

\begin{tabular}{|c|c|c|c|c|c|c|c|c|c|}
\hline \multirow{2}{*}{$\frac{\text { Patients }}{\text { All }(n=307)}$} & \multicolumn{3}{|c|}{$\begin{array}{l}\text { Early mortality rate } \\
\text { (no. of deaths) }\end{array}$} & \multicolumn{3}{|c|}{$\begin{array}{l}\text { Late mortality rate } \\
\text { (no. of deaths) }\end{array}$} & \multicolumn{3}{|c|}{$\begin{array}{l}\text { Total mortality rate } \\
\text { (no. of deaths) }\end{array}$} \\
\hline & $7.5 \%$ & $(23)$ & & $10.7 \%$ & (29) & & $16.9 \%$ & $(52)$ & \\
\hline Group $1(n=95)$ & $2 \%$ & (2) & $\left(\alpha^{1}\right)$ & 0 & & $\left(\alpha^{2}\right)$ & $2 \%$ & (2) & $(\alpha)$ \\
\hline Group $2(n=102)$ & $2 \%$ & (2) & $\left(\beta^{1}\right)$ & $4 \%$ & (4) & $\left(\beta^{2}\right)$ & $6 \%$ & (6) & $(\beta)$ \\
\hline Group $3(n=110)$ & $17 \%$ & (19) & $\left(\chi^{1}\right)$ & $28 \%$ & $(25)$ & $\left(x^{2}\right)$ & $40 \%$ & (44) & $(\chi)$ \\
\hline \multicolumn{10}{|l|}{ Group 3} \\
\hline $1983-1989(n=61)$ & & & & & & & $49 \%$ & (30) & $(\delta)$ \\
\hline $1990-1994(n=49)$ & & & & & & & $29 \%$ & (14) & (द) \\
\hline \multicolumn{10}{|l|}{ Group 3} \\
\hline Staged repair $(n=79)$ & & & & & & & $47 \%$ & $(37)$ & $(\phi)$ \\
\hline Primary repair $(n=31)$ & & & & & & & $23 \%$ & (7) & $(\gamma)$ \\
\hline \multicolumn{10}{|l|}{ TGA-DORV } \\
\hline Staged repair $(n=44)$ & & & & & & & $45 \%$ & $(20)$ & $(\eta)$ \\
\hline Primary repair $(n=27)$ & & & & & & & $19 \%$ & (5) & $(\lambda)$ \\
\hline
\end{tabular}

Group 1, Isolated coarctation; group 2, coarctation with VSD; group 3, coarctation with complex heart defects; TGA, transposition of the great arteries; DORV, double-outlet right ventricle. $\alpha$ versus $\beta$ or $\chi: p<0.001 ; \alpha^{1}$ versus $\beta^{1}$ or $\chi^{1}, p<0.001 ; \alpha^{2}$ versus $\beta^{2}$ or $\chi^{2}, p<0.001 ; \delta$ versus $\epsilon, p<0.05 ; \phi$ versus $\gamma, p<$ $0.05 ; \eta$ versus $\lambda, p<0.05$.

Morbidity. Persistent respiratory failure occurred in 16 patients and persistent left ventricular dysfunction in 12. Fourteen patients having had an adequate coarctation repair had a persistent postoperative hypertension. Left phrenic nerve paralysis was detected in two patients who underwent additional $\mathrm{PAB}$; in one it was reversible, but in the other it necessitated surgical diaphragm plication. Chylothorax was present in three patients, and one of them required thoracic duct ligation. One patient had thrombosis of the superior vena cava and required surgical management. Postoperative paraplegia or neurologic complications were not encountered.
Recoarctation. Thirty patients had a recoarctation $(9.8 \%$; CL $6.4 \%$ to $13.1 \%$ ) after a mean time of $4 \pm 3$ months (range 1 to 11 months) from the repair. Recoarctation rates in patients operated on through a thoracotomy $(10 \%)$ and through a sternotomy $(8.3 \%)$ were not significantly different. All but one of the patients in whom a recoarctation developed initially had some form of aortic arch hypoplasia $(p<0.001)$.

Furthermore, recoarctation occurred in $12 \%$ of all the patients with aortic arch hypoplasia and in $2 \%$ of all those without aortic arch hypoplasia $(p<$ $0.05)$. According to aortic arch hypoplasia types, 


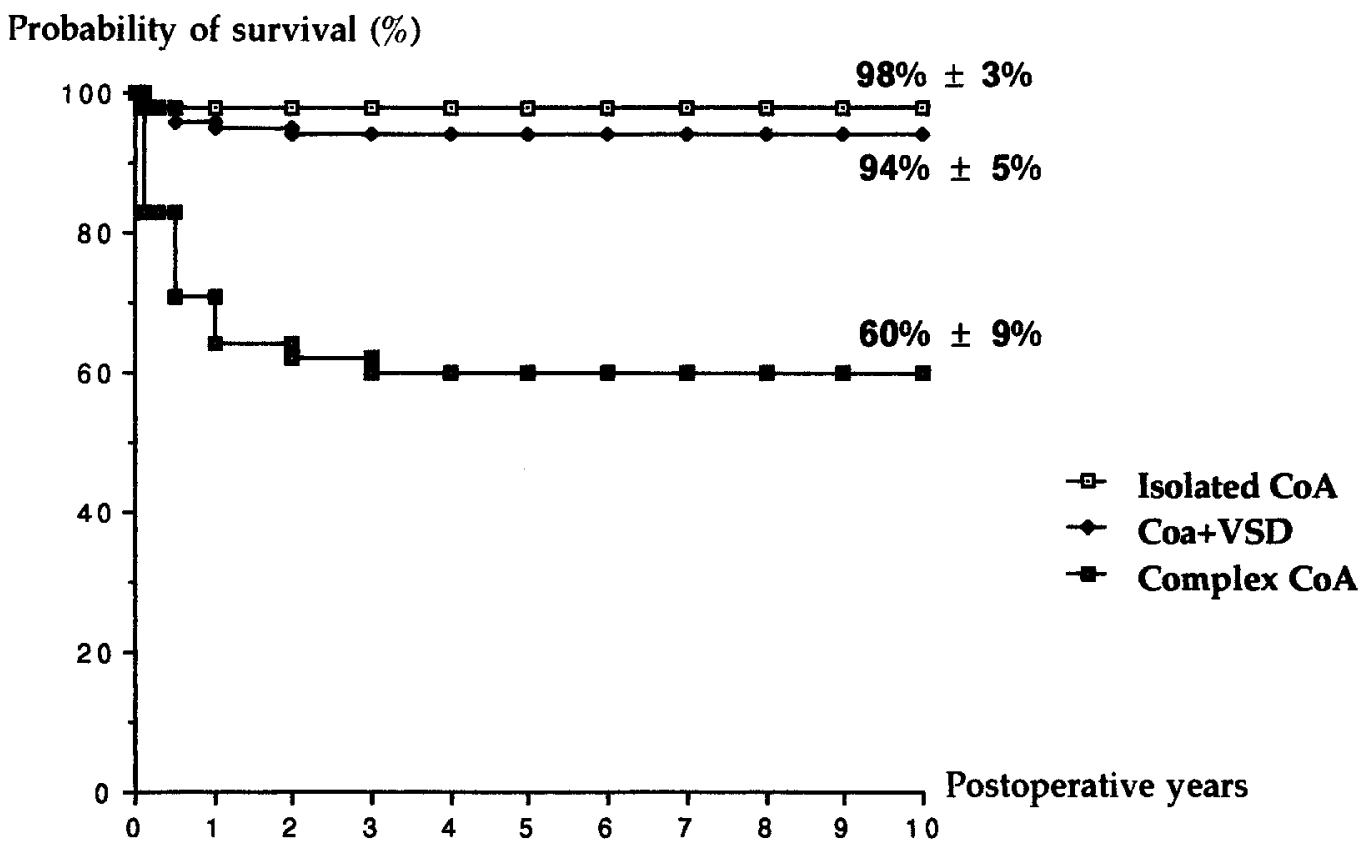

Fig. 4. Actuarial probability of survival according to associated cardiac anomalies. $C O A$, Coarctation; VSD, ventricular septal defect; Complex $\operatorname{CoA}$, coarctation with associated complex heart defects.

Table IV. Influence of surgical approach, arch hypoplasia, and associated cardiac anomalies on recoarctation

\begin{tabular}{lcc}
\multicolumn{1}{c}{ Variable } & \multicolumn{2}{c}{ Recoarctation no. } \\
$(\%)$
\end{tabular}

$A A H$, Aortic arch hypoplasia; group 1, isolated coarctation; group 2, coarctation with VSD; group 3, coarctation with complex heart defects. $\alpha$ versus $\beta, p=$ n.s.; $\chi$ versus $\delta, p<0.05 ; \epsilon$ versus $\phi$ or $\gamma, p<0.001 ; \phi$ versus $\gamma, p<0.01 ; \eta$ versus $\lambda$ or $\mu, p<0.05$.

recoarctation occurred in $4 \%$ of the patients with distal aortic arch hypoplasia, $20 \%$ of the patients with complete aortic arch hypoplasia, and $55 \%$ of the patients with complex aortic arch hypoplasia. Therefore patients with more extended aortic arch hypoplasia were at a significantly higher risk for recoarctation $(p<0.001)$. According to patient groups, recoarctation occurred in three patients in group $1(3 \%), 13$ patients in group $2(13 \%)$, and 14 patients in group $3(13 \%)$. Therefore patients with an associated major intracardiac lesion were at a significantly higher risk of recoarctation $(p<0.05)$ (Table IV). According to the timing of diagnosis, residual coarctation occurred in nine patients (2.9\%; CL $1 \%$ to $4.8 \%$ ) and it was attributed in four early cases to the lack of experience and in the remaining five to an extreme form of complex aortic arch hypoplasia. Recurrent coarctation was detected in 21 patients $(7.8 \%$; CL $4.6 \%$ to $11 \%)$ : nine patients with recoarctation proximal to the anastomosis and therefore associated with an insufficient extension of the aortic arch incision, six patients in whom recoarctation was probably related to incomplete resection of ductal tissue, and six patients with a severe form of complex aortic arch hypoplasia.

The actuarial probability of freedom from recoarctation at 10 years was $90 \% \pm 4 \%$ (Fig. 5 ).

Twenty-four patients underwent successful reoperation $(n=21)$ or transfemoral balloon angioplasty $(n=3)$ for recoarctation 1 to 26 months (mean $8 \pm$ 7 months) after the initial repair. Surgical procedures included extended end-to-end anastomosis in eight patients, extended end-to-end anastomosis plus subclavian artery resection in four, subclavian flap aortoplasty ${ }^{14}$ in four, extended end-to-end anastomosis plus reversed subclavian flap aortoplasty ${ }^{15}$ in three, and reversed subclavian flap aortoplasty in 


\section{Probability of freedom (\%)}

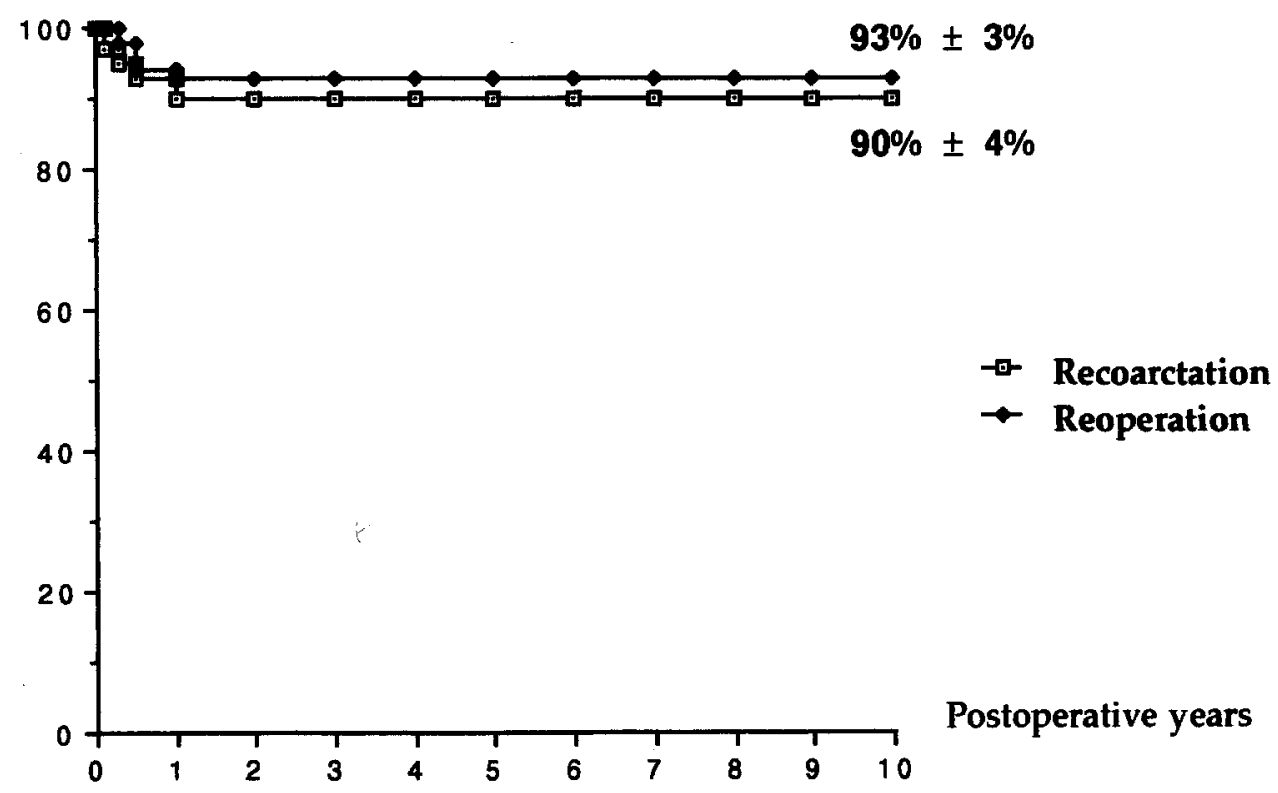

Fig. 5. Actuarial probability of freedom from recoarctation and freedom from reoperation for recoarctation.

two. Of the 13 patients in whom recoarctation repair was performed by using subclavian artery resection or flap (anterograde or retrograde) aortoplasty, 10 patients $(77 \%)$ had a complex aortic arch hypoplasia $(p<0.02)$.

There were no deaths or major complications at reoperation. Of the three patients who underwent balloon angioplasty, one later had an aortic aneurysm $(33 \%)$.

Freedom from reoperation for recoarctation 10 years after the operation was 93\% $\pm 3 \%$ (see Fig. 5).

\section{Discussion}

Although the outcome of neonatal coarctation repair, as judged by mortality, morbidity, and recoarctation, has dramatically improved in the last years, optimal surgical management is still under debate. Main controversies are essentially two: the technique of choice according to the aortic arch anatomy and the surgical approach according to the repair of associated heart defects. The data presented in this retrospective study on the largest reported series of neonates undergoing coarctation repair revealed a number of interesting findings that specifically address such controversies.

Technique of choice. Some degree of aortic arch hypoplasia is often present in the neonate with aortic coarctation. ${ }^{7,9,11}$ In the past, several autopsy reports emphasized the frequency of this association. ${ }^{8,13,16,17}$ In this study aortic arch hypoplasia was present as an additional lesion in $81 \%$ of the patients. Significant prevalence of aortic arch hypoplasia in similar patients referred for operation has already been observed by us ${ }^{12}$ and by others, ${ }^{18,} 19$ and probably it is a simple consequence of the increasing incidence of the presentation of neonates for coarctation repair after the introduction of preoperative prostaglandin $E_{1}$ therapy. ${ }^{20}$ It can be inferred that most of the neonates with aortic coarctation and arch hypoplasia were seen in the past by the pathologist; now they are treated by the surgeon. ${ }^{12}$ The presence of a hypoplastic arch usually increases the left ventricular obstruction created by the coarctation. It has already been emphasized that the extended end-to-end anastomosis is the surgical technique that relieves such an obstruction more effectively. ${ }^{3-6,12,18,19,21,22}$ Furthermore, this procedure seems to be free from most of the disadvantages of the classic techniques: standard end-to-end anastomosis, ${ }^{23}$ subclavian flap aortoplasty, ${ }^{14}$ and synthetic patch aortoplasty. ${ }^{24}$ High prevalence of recoarctation was widely reported for neonatal coarctation repair by both end-to-end anastomosis $^{10,25}$ and subclavian flap ${ }^{20,26,27}$ or synthetic patch ${ }^{28,29}$ aortoplasties. Recoarctation was 
mainly attributed to growth failure of the anastomo$\mathrm{sis}^{30}$ or to an inadequate resection of the ductal tissue $^{31}$ as regards end-to-end anastomosis, and to persistence and development of the coarctation shelf as regards subclavian flap or synthetic patch aortoplasties. ${ }^{32-34}$ Several histologic examinations showed the presence of a circumferential sling of ductal tissue extending from the ductus arteriosus and surrounding the aorta at the level of the coarctation shelf. ${ }^{8,35,36}$ Proliferation and constriction of residual ductal tissue, still active in the neonatal period, ${ }^{7}$ would make postoperative recurrence more likely. ${ }^{33,37}$ Late aneurysm formation is another widely recognized disadvantage of subclavian flap aortoplasty $^{38}$ and synthetic patch aortoplasty. ${ }^{39}$ With regard to subclavian flap aortoplasty, moreover, shortening and claudication of the left arm, ${ }^{34,40,41}$ gangrene of the left arm, ${ }^{42}$ subclavian steal syndrome, ${ }^{40}$ and Horner's syndrome ${ }^{19}$ were reported as well.

Concerns about these complications and awareness of the increased prevalence of aortic arch hypoplasia stimulated the development of extended end-to-end anastomosis to provide an adequate and safe neonatal coarctation repair. In our opinion, for a normal aortic arch to be restored, three major key points should be respected: (1) a wide dissection and mobilization of the entire thoracic aorta, (2) a large resection of the coarctation including all ductal tissue, and (3) an incision in the arch concavity extended beyond the origin of the left carotid artery. Nonobservance of these points may increase the risk of recoarctation because of excessive tension on the suture line in the first case, ${ }^{10}$ molding of ductal tissue in the second case,,$^{10,31,37}$ and inadequate anastomotic size or insufficient relief of the obstruction present at the transverse arch level in the third case. ${ }^{5,6,12}$ However, when arch hypoplasia is absent or distal, a more limited arch incision can be sufficient to allow adequate repair.

In this study, recoarctation rate and freedom from reoperation for recoarctation at 10 years after the initial repair were, respectively, $9.8 \%$ and $93 \% \pm$ $3 \%$. Others reported similar results with extended end-to-end anastomosis, $5,18,19,21,22$ although their series did not contain exclusively neonates and actuarial estimates were not so extended. In our patients the occurrence of recoarctation was significantly influenced by the presence of aortic arch hypoplasia, and particularly by the complex type $(p<0.001)$. The association with a major intracardiac defect resulted in an increasing risk of recoarctation as well $(p<0.05)$. This observation is not particularly surprising, because aortic arch hypoplasia was significantly more common and extensive in patients with an associated major intracardiac defect $(p<0.001)$. This concomitance seems to strongly support the hemodynamic underdevelopment theory for the pathogenesis of aortic coarctation. ${ }^{7}$

In view of the findings here presented, a more flexible approach can be advocate as regards complex aortic arch hypoplasia. This uncommon form of arch hypoplasia ( $7 \%$ of our patients), in which a very short proximal arch is associated with an elongated and narrow distal arch, very often was extremely difficult to repair. When there is virtually no proximal arch (left carotid artery arising very close to or as a branch of the innominate artery), it may not be possible to place the upper aortic clamp proximal to the entire hypoplastic segment without seriously compromising flow to the innominate artery during clamping. In this case with a so called "bovine" innominate trunk, ${ }^{11}$ arch repair by an anterior approach with CPB and deep hypothermic circulatory arrest is certainly preferable. In this series 13 patients had such a lesion: eight underwent successful repair via sternotomy, and the remaining five, who were trated via left thoracotomy, all had a postoperative recoarctation. Furthermore, complex aortic arch hypoplasia often includes another anatomic variant, an extremely long distal arch. We think that in this case adequate repair requires the use of extended end-to-end anastomosis in addition to sacrifice of the left subclavian artery; this artery can be used as an antegrade or reversed flap to augment the top of the distal arch or it can simply be ligated to allow the resection of part of the distal arch. In this series 17 patients had this anatomic variant. Subclavian artery resection and flap aortoplasty were part of the initial successful repair in seven of these patients and were used in the reoperation for recoarctation of the remaining 10 .

The potential for spinal chord ischemia (performing a long anastomosis) and brain damage (clamping most of the head vessels) could be of great concern with extended end-to-end anastomosis. However, in our patients these complications were not encountered. Other recent reports of similar series were also free from paraplegia or cerebral injury after extended end-to-end anastomosis. ${ }^{18,} 19,22$ In our experience, continuous monitoring of adequate blood pressure by a right radial artery line during clamping and great care to keep the clamp time shorter than 
40 minutes have been satisfactory measures to preserve the brain and spinal chord.

Percutaneous balloon aortoplasty has been proposed as a primary coarctation repair, but this technique would appear to have the same disadvantages as other surgical aortoplasties (subclavian flap or synthetic patch). Recoarctation may occur frequently ${ }^{43}$ because ductal tissue is not removed, and aortic aneurysm may develop. ${ }^{44}$ Furthermore, vascular complications at the introduction site of the catheter may occur. ${ }^{45}$ Although impressive results have been reported after balloon dilation for postoperative recoarctation, ${ }^{44,}{ }^{46}$ we observed late aneurysm formation in a patient treated with this technique $(33 \%)$. Since our experience with reoperation for recoarctation is free from mortality and major morbidity, surgery continues to be our treatment of choice for recoarctation.

In our patients extended end-to-end anastomosis was performed with continuous $6-0$ polypropylene suture. Although superiority of absorbable suture has been advocated by some authors, $5,18,21,33,47$ a sudden unexplained death in a neonate treated with such a suture material was reported, ${ }^{20}$ and others recently observed no difference in the prevalence of recoarctation between infants undergoing coarctation repair with either absorbable or nonabsorbable sutures. ${ }^{19,33}$ Furthermore, satisfactory anastomotic growth was observed by us ${ }^{48}$ and by others ${ }^{20,37,49}$ in neonates undergoing arterial switch operations with the same suture technique and material here reported.

Surgical approach. As regards the group of patients with coarctation and associated VSD, the lateral approach was the most frequently used in this series $(95 \%)$. Encouraging results have been reported for complete repair by means of an anterior approach. ${ }^{50-53}$ We used such an approach for patients either with a single large VSD (infundibular type) or with severe complex aortic arch hypoplasia. Because spontaneous VSD closure has been observed frequently in this series (39\%) and in others $(80 \%),{ }^{54}$ in recent years we began to limit the use of $\mathrm{PAB}$ to the palliation of multiple VSDs.

In this study the most important risk factor for postoperative death was the association of complex cardiac lesions. Differences of early, late, and total mortality rates among patients with complex heart defects and patients with either isolated coarctation or associated VSD were highly significant $(p<$ 0.001 ). Similar findings have been reported from several authors. ${ }^{12,18-22,29}$ Critical preoperative sta- tus is another well-defined risk factor for early death, ${ }^{19,20}$ although it is becoming less common. Intensive preoperative management (including prostaglandin $E_{1}$ administration, artificial ventilation, and inotropic support) and the increasing use of echocardiography in place of angiography were mainly responsible for the better outcome recently reported. ${ }^{18,20,29}$ They allow operations to be performed in patients in more stable hemodynamic condition. Other risk factors for death, such as very young age or small size at operation, ${ }^{20,22,33}$ often appear in conjunction with complex cardiac lesions.

In this series, the actuarial survivals at 10 years after operation for patients with isolated coarctation or coarctation associated with VSD or with complex cardiac anomalies were, respectively, 98\%, 94\%, and $60 \%$. Kirklin, ${ }^{10}$ Vouhé, ${ }^{18}$ Van Heurn, ${ }^{19}$ Ziemer, ${ }^{20}$ Harlan, ${ }^{21}$ Trinquet, ${ }^{22}$ and their associates reported actuarial survivals at 5 years ranging from $80 \%$ to $96 \%$ for infants with isolated coarctation, from $62 \%$ to $90 \%$ for infants with associated VSD, and from $15 \%$ to $43 \%$ for infants with associated complex heart defects. The improved results here presented have special significance because this series contains exclusively neonates, and it is by far larger than the others recently published. The major improvement in survival undoubtedly occurred in patients with associated complex anomalies. The changing policy with regard to surgical strategy has been largely responsible for such an improvement. In the past 5 years, one-stage repair via sternotomy for patients of this group increased from $8 \%$ to $53 \%$ $(p<0.001)$. During the same period mortality in this group decreased from $49 \%$ to $29 \%(p<0.05)$. Furthermore, a significant difference resulted from comparison of mortality rates in patients treated by means of the primary $(26 \%)$ or staged approach $(46 \%)(p<0.05)$. Interestingly, in the aforementioned series a large majority of the patients with complex heart defects were treated by means of a staged approach. ${ }^{10,18-22}$ In consideration of the poor results obtained with this approach, a complete repair during a one-stage procedure through a median sternotomy has therefore been advocated. ${ }^{10,19}$ Several reports have shown that aortic arch reconstruction with concomitant repair of the associated lesions is feasible and gives better results. ${ }^{50-53}$ In our series, this approach has been used mainly $(87 \%)$ for patients with associated TGA or DORV (Taussig-Bing type). These anomalies were the associations more frequently encountered $(65 \%)$. In patients with these associated anomalies, deleterious 
effects of PAB and better outcome provided by onestage repair have been recently reported by our group. ${ }^{55}$ In this study comparison of mortality rates after one-stage and two-stage repair in these patients showed a significant difference $(p<0.05)$.

Among complex associations, it is possible to identify two other main categories of lesions: left-sided obstructive lesions (aortic stenosis, mitral stenosis, subaortic stenosis, hypoplastic left ventricle) and univentricular heart. In the first group, also termed hypoplastic left heart syndrome class II or III, ${ }^{10}$ the surgical management was associated in this series and in others recently reported ${ }^{11,53}$ with high mortality, and indications for two- or single-ventricle repair mainly depend on the number of associations ${ }^{10}$ and on careful evaluation of many morphologic and functional parameters of the left side of the heart. ${ }^{56} \mathrm{In}$ patients with univentricular heart, a palliative procedure, in view of a subsequent Fontan operation, is always indicated. The choice of the palliation for patients with indications for single ventricle repair is a difficult one. Although PAB has been commonly used, concerns about deleterious effects on suitability of the Fontan operation, such as impaired diastolic function related to the myocardial hypertrophy generated by the $\mathrm{PAB},{ }^{57}$ stimulated many surgeons to consider other options: the Damus-Kay-Stansel procedure, palliative arterial switch, and Norwood-type procedure. ${ }^{57-59}$ Regarding the Norwood procedure, a biologic patch-graft augmentation of the aortic end-toend anastomosis ${ }^{60}$ through an anterior approach appears to be an attractive alternative in some cases in which, with wide aortic dissection, arch reconstruction by means of direct anastomosis would be not feasible without any excessive tension. Complete relief of the aortic arch obstruction (mandatory in patients with left-sided obstructive lesions) and easy reproducibility are the major advantages of the ascending aorta/arch augmentation. ${ }^{61}$

In conclusion, we have described our 11 years' experience with the surgical management of neonatal coarctation. Because improvements in preoperative management (e.g., prostaglandin $\mathrm{E}_{1}$ therapy, echocardiography in place of angiography) allowed an increasing number of neonates to be referred for coarctation repair, a higher prevalence of associated aortic arch hypoplasia in these patients was evident. Both operative mortality and recoarctation rates have been generally higher for coarctation repair in patients in this age group. Main reasons for this are the associations with aortic arch hypoplasia and complex heart defects. The findings of this study suggest that extended end-to-end anastomosis safely provides an adequate reconstruction of the aortic arch in patients in this age group. The main advantage of this technique is the effective relief of left ventricular obstruction created by aortic arch hypoplasia. Furthermore, extended end-to-end anastomosis is associated with low operative mortality and low probability of recurrence, and it is applicable via both anterior and lateral approaches. Freedom from major morbidity, absence of foreign material, complete resection of ductal tissue, and preservation of the left sublavian artery are other advantages of this technique. In some cases with a severe form of arch hypoplasia, some sort of arch augmentation by means of a subclavian flap or a homograft patch could be preferable. Successful management of the majority of neonates with associated ventricular septal defect is possible with repair of coarctation alone. Early VSD repair or PAB should be considered in patients in whom medical management of postoperative congestive heart failure is unsuccessful. Indications for PAB should be limited to the palliation of multiple VSDs. Survival in patients with additional complex cardiac lesions is mainly related to the severity of the associated anomalies. One-stage repair of neonatal coarctation and associated complex heart defects (with indication for two-ventricle repair) by means of an anterior approach provides a better outcome than a two-stage repair.

We thank Dr. André Capderou for his contribution to statistical analysis.

\section{REFERENCES}

1. Mustard WT, Rower RD, Keith JD, Sirek A. Coarctation of the aorta with special reference to the first year of life. Ann Surg 1955;141:249-52.

2. Olley PM, Coceani F, Bodach E. E-type prostaglandins: a new emergency therapy for certain cyanotic congenital heart malformations. Circulation 1976;53:728-31.

3. Zannini L, Lecompte $Y$, Galli R, et al. La coartazione aortica con ipoplasia dell'arco: descrizione di una nuova tecnica chirurgica. G Ital Cardiol 1985;15:1045-8.

4. Vincent JG, Daniels O, Van Oort A, Lacquet LK. Hypoplastic aortic arch with aortic coarctation: surgical correction. J Thorac Cardiovasc SuRg 1985;89:465-8.

5. Lansman S, Shapiro AJ, Schiller MS, et al. Extended aortic arch anastomosis for repair of coarctation in infancy. Circulation 1986;74(Suppl):I37-41.

6. Elliott MJ. Coarctation of the aorta with arch hypoplasia: improvements on a new technique. Ann Thorac Surg 1987;44:321-3.

7. Rudolph AM, Heymann MA, Spitznas U. Hemody- 
namic consideration in the development of narrowing of the aorta. Am J Cardiol 1972;30:514-25.

8. Ho SY, Anderson RH. Coarctation, tubular hypoplasia, and the ductus arteriosus: histological study of 35 specimens. Br Heart J 1979;41:268-74.

9. Morrow WR, Huhta JC, Murphy DJ, McNamara DG. Quantitative morphology of the aortic arch in neonatal coarctation. J Am Coll Cardiol 1986;8:616-20.

10. Kirklin JW, Barratt-Boyes BG. Coarctation of the aorta and aortic arch interruption. In: Kirklin JW, Barratt-Boyes BG, eds. Cardiac surgery. 2nd ed. New York: Churchill Livingstone, 1993:1263-325.

11. Castaneda AR, Jonas RA, Mayer JE, Hanley FL. Aortic coarctation. In: Castaneda AR, Jonas RA, Mayer JE, Hanley FL, eds. Cardiac surgery of the neonate and infant. 1st ed. Philadelphia, WB Saunders, 1994:333-52.

12. Lacour-Gayet F, Bruniaux J, Serraf A, et al. Hypoplastic transverse arch and coarctation in neonates: surgical reconstruction of the aortic arch-a study of sixty-six patients. J THORAC CARDIOvasc SuRg 1990; 100:808-16.

13. Moulaert AJ, Bruins CC, Oppenheimer-Dekker A. Anomalies of the aortic arch and ventricular septal defects. Circulation 1976;53:1011-5.

14. Waldhausen JA, Nahrwold DL. Repair of coarctation of the aorta with a subclavian flap. J THORAC CARDIOVASC SURG 1966;51:532-3.

15. Hart JC, Waldhausen JA. Reversed subclavian flap angioplasty for arch coarctation of the aorta. Ann Thorac Surg 1983;36:715-7.

16. Becker AE, Becker J, Edwards JE. Anomalies associated with coarctation of the aorta: particular reference to infancy. Circulation 1970;41:1067-75.

17. Bharati S, Lev M. The surgical anatomy of the heart in tubular hypoplasia of the transverse aorta (preductal coarctation). J THORAC CARDIOVASC SuRG 1986;91: $79-85$.

18. Vouhé $\mathrm{P}$, Trinquet F, Lecompte $\mathrm{Y}$, et al. Aortic coarctation with hypoplastic aortic arch. J THORAC Cardiovasc Surg 1988;96:557-63.

19. Van Heurn LWE, Wong CM, Spiegelhalter DJ, et al. Surgical treatment of aortic coarctation in infants younger than three months: 1985 to 1990 . Success of extended end-to-end arch aortoplasty. J THORAC CARDIOVASC SuRG 1994;107:74-86.

20. Ziemer G, Jonas RA, Perry SB, Freed MD, Castaneda AR. Surgery for coarctation of the aorta in the neonate. Circulation 1986;74(Suppl):I25-31.

21. Harlan JL, Doty DB, Brandt B, Ehrenhaft JL. Coarctation of the aorta in infants. J Thorac CardiovasC SURG 1984;88:1012-9.

22. Trinquet F, Vouhe $P$, Vernant F, et al. Coarctation of aorta in infants. Which operation? Ann Thorac Surg 1988;45:186-91.

23. Crafoord C, Nylin G. Congenital coarctation of the aorta and its surgical treatment. J THORAC CARDIOVASC SURG 1945;14:347-61.

24. Vossschulte K. Isthmusplastik zur Behandlung der Aortenisthmusstenose. Thoraxchirurgie 1957;4:443-50.

25. Tawes RL, Aberdeen E, Waterston DJ, Carter REB. Coarctation of the aorta in infants and children: a review of 333 operative cases including 170 infants. Circulation 1969;39(Suppl):I173-84.

26. Metzdorff MT, Cobanoglu A, Grunkemeier GL, Sunderland CO, Starr A. Influence of age at operation on late results with subclavian flap aortoplasty. J THORAC Cardiovasc Surg 1985;89:235-41.

27. Campbell DB, Waldhausen JA, Pierce WS, Fripp R, Whitman V. Should elective repair of coarctation of the aorta be done in infancy. J Thorac Cardiovasc SURG 1984;88:929-38.

28. Hesslein PS, McNamara DG, Morris MJH, Hallman G, Cooley D. Comparison of resection versus patch aortoplasty for repair of coarctation in infants and children. $J$ Thorac Cardiovasc Surg 1991;102:596-601.

29. Shrivastava CP, Monro JL, Shore DF, et al. The early and long-term results of surgery for coarctation of the aorta in the 1st year of life. Eur J Cardiothorac Surg 1991;5:61-6.

30. Ibarra-Perez C, Castaneda AR, Varco RL, Lillehei C. Recoarctation of the aorta: nineteen years clinical experience. Am J Cardiol 1969;23:778-84.

31. Korfer R, Meyer H, Kleikamp G, Bircks W. Early and late results after resection and end-to-end anastomosis of coarctation of the thoracic aorta in early infancy. J Thorac Cardiovasc Surg 1985;89:616-22.

32. Sanchez GR, Balsara RK, Dunn JM, Mehta AV, O'Riordan AC. Recurrent obstruction after subclavian flap repair of coarctation of the aorta in infants: Can it be predicted or prevented? J THORAC CARDIOVASC SURG 1986;91:738-46.

33. Cobanoglu A, Teply JF, Grunkemeier GL, Sunderland $\mathrm{CO}$, Starr A. Coarctation of the aorta in patients younger than three months: a critique of the subclavian flap operation. J Thorac Cardiovasc Surg 1985;89:128-35.

34. Van Son JAM, Daniels O, Vincent JG, Van Lier HJJ, Lacquet LK. Appraisal of resection and end-to-end anastomosis for repair of coarctation of the aorta in infancy: preference for resection. Ann Thorac Surg 1989;49:496-502.

35. Elzenga NJ, Gittenberger-De Groot AC. Localised coarctation of the aorta: an age dependent spectrum. Br Heart J 1983;49:317-23.

36. Russel GA, Berry PJ, Watterson K, Dhasmana JP, Wisheart JD. Patterns of ductal tissue in coarctation of the aorta in the first three months of life. J THORAC Cardiovasc Surg 1991;102:596-601.

37. Jonas RA. Coarctation: Do we need to resect ductal tissue? Ann Thorac Surg 1991;52:604-7.

38. Martin MM, Beekman RH, Rocchini AP, et al. Aortic 
aneurysm after subclavian angioplasty repair of coarctation of the aorta. Am J Cardiol 1988;61:951-3.

39. Del Nido PJ, Williams WG, Wilson GJ, et al. Synthetic patch angioplasty for repair of coarctation of the aorta: experience with aneurysm formation. Circulation 1986;74(Suppl):I32-6.

40. Todd PJ, Dangerfield PH, Hamilton DI, Wilkinson JL. Late effects on the left upper limb of subclavian flap aortoplasty. J Thorac Cardiovasc Surg 1983; 85:678-87.

41. Van Son JAM, Van Asten WNJC, Van Lier HJJ, et al. Detrimental sequelae on the hemodynamics of the upper left limb after subclavian flap angioplasty in infancy. Circulation 1990;81:996-1004.

42. Geiss D, Williams WG, Lindsay WK, Rowe RD. Upper extremity gangrene: a complication of subclavian artery division. Ann Thorac Surg 1980;30:487-9.

43. Rao PS, Thapar MK, Kutayli F, Carey P. Causes of recoarctation after balloon angioplasty of unoperated aortic coarctation. J Am Coll Cardiol 1989;13:109-15.

44. Lock JE. Now that we can dilate, should we? Am J Cardiol 1984;54:1360.

45. Finley JP, Beaulieu RG, Nanton MA, Roy DL. Balloon catheter dilatation of coarctation of the aorta in young infants. Br Heart J 1983;50:411-5.

46. Kan JS, White RI, Mitchell SE, Farmlett EJ, Donhado JS, Gardner TJ. Treatment of restenosis of coarctation by percutaneous transluminal angioplasty. Circulation 1983;68:1087-94.

47. Myers JL, McConnell BA, Waldhausen JA. Coarctation of the aorta in infants: Does the aortic arch grow after repair? Ann Thorac Surg 1992;54:869-75.

48. Planchè C, Bruniaux J, Lacour-Gayet $F$, et al. Switch operation for transposition of the great arteries in neonates: a study of 120 patients. J THORAC CARDIOVASC SURG 1988;96:354-63.

49. Aresman FW, Sievers HH, Lange P, et al. Assessment of coronary and aortic anastomosis after anatomic correction of transposition of the great arteries. J Thorac Cardiovasc Surg 1985;90:597-604.

50. Bergdahl LAL, Blackstone EH, Kirklin JW, Pacifico $\mathrm{AD}$, Bargeron LM. Determinants of early success in repair of aortic coarctation in infants. $\mathrm{J}$ THORAC CardiovasC SuRg 1982;83:736-42.

51. Ungerleider RM, Ebert PA. Indications and techniques of midline approach to aortic coarctation in infants and children. Ann Thorac Surg 1987;44:51722.

52. Karl TR, Sano S, Brawn W, Mee RBB. Repair of hypoplastic or interrupted aortic arch via sternotomy. J Thorac Cardiovasc Surg 1992;104:688-95.

53. Hazekamp MG, Quaegebeur JM, Singh S, et al. One stage repair of aortic arch anomalies and intracardiac defects. Eur J Cardiothorac Surg 1991;5:283-7.

54. Park JK, Dell RB, Ellis K, Gersony WB. Surgical management of the infant with coarctation of the aorta and ventricular septal defect. J Am Coll Cardiol 1992;20:176-80.

55. Planché C, Serraf A, Comas JV, Lacour-Gayet F, Bruniaux J, Touchot A. Anatomic repair of transposition of the great arteries with ventricular septal defect and aortic arch obstruction: one-stage versus two-stage procedure. J Thorac Cardiovasc Surg 1993;105:925-33.

56. Rhodes LA, Colan SD, Perry SB, Jonas RA, Sanders SP. Predictor of survival in neonates with critical aortic stenosis. Circulation 1991;84:2325-35.

57. Freedom RM, Benson LN, Smallhorn JF, Williams WG, Rowe RD. Subaortic stenosis, the univentricular heart, and banding of the pulmonary artery: an analysis of the courses of 43 patients with univentricular heart palliated by pulmonary artery banding. Circulation 1986;73:757-64.

58. Jonas RA, Castaneda AR, Lang P. Single ventricle (single or double-inlet) complicated by subaortic stenosis: surgical options in infancy. Ann Thorac Surg 1985;39:361-6.

59. Lacour-Gayet F, Serraf A, Fermont L, et al. Early palliation of univentricular hearts with subaortic stenosis and ventriculoarterial discordance: the arterial switch option. J Thorac Cardiovasc SuRg 1992;104:1238-45.

60. Edmunds LH, Norwood WI, Low DW. Atlas of cardiothoracic surgery. Philadelphia: Lea \& Febiger, 1990:154-5, Figs. 2-5.

61. Jonas RA, Quaegebeur JM, Kirklin JW, Blackstone EH, Daicoff G. Outcome in patients with interrupted aortic arch and ventricular septal defect: a multiinstitutional study. J THORAC CARDIOvASC SuRg 1994;107: 1099-113.

\section{Discussion}

Dr. William S. Blakemore (Birmingham, Ala.). On the illustrations you used a continuous suture. I can recall that shortly after World War II, Julian Johnson and a group of us worked in an animal laboratory using interrupted sutures at least on the anterior surface. We were also using silk as our continuous suture in the experiment.

Perhaps a more difficult and more pertinent question is this: Do you have any idea what causes the aortic arch deformities in this group of patients? I ask this because as we worked in a rural area in starting a program we thought we saw an extraordinary number of aortic arch deformities in the patients from the rural countryside. They had surface water wells. They planted corn up to the house, and the well was beside the house. We were concerned that herbicides or insecticides might be having an effect in the pregnant women, especially at the critical times of about 12 weeks. Do you have any thoughts about what might be causing these kinds of deformities?

Dr. William A. Gay, Jr. (Bronx, N.Y.). Have you had any untoward events from your angioplasty for the recoarctations? Have you had to operate on any of these patients 
urgently? At what time after repair of a coarctation do you believe that it is safe to dilate the anastomosis?

Dr. Lacour-Gayet. I thank the discussants for their comments.

To answer the questions of Dr. Blakemore: Regarding the use of continuous suture, we feel quite comfortable with this technique because we have now performed 600 arterial switches in neonates using continuous suture with a nonabsorbable monofilament on the aortic anastomosis without observing stenosis. Regarding the difficult question on the etiology of aortic arch hypoplasia: It is clear that this hypoplasia takes place during pregnancy, and several hypotheses have been suggested, among them the malalignment of the conal septal. However, I can tell that true malalignment VSD is not always associated with aortic arch obstruction, for severe arch hypoplasia can be seen in the absence of malaligned conal septum. Therefore, other causes still under investigation might be responsible for this anomaly.

To answer the question of Dr. Gay regarding the indications of angioplasty: We have not attempted to indicate balloon dilatation in native coarctation. For patients with recoarctation, the results obtained after balloon dilatation are good, as similarly observed by the group from Boston. The aorta is surrounded by fibrous tissue and we believe that the risk of bleeding is not very important. On the other hand, all reoperations for recoarctation in this series were achieved without mortality.

\section{Bound volumes available to subscribers}

Bound volumes of The Journal of Thoracic And Cardiovascular Surgery are available to subscribers (only) for the 1995 issues from the Publisher, at a cost of $\$ 91.00$ for domestic, $\$ 118.77$ for Canadian, and $\$ 111.00$ for international subscribers for Vol. 109 (January-June) and Vol. 110 (July-December). Shipping charges are included. Each bound volume contains a subject and author index and all advertising is removed. Copies are shipped within 60 days after publication of the last issue of the volume. The binding is durable buckram with the JournaL name, volume number, and year stamped in gold on the spine. Payment must accompany all orders. Contact Mosby-Year Book, Inc., Subscription Services, 11830 Westline Industrial Drive, St. Louis, Missouri 63146-3318, USA; phone 1 (800) 453-4351 or (314) 453-4351.

Subscriptions must be in force to qualify. Bound volumes are not available in place of a regular JouRNal subscription. 